University of Nebraska - Lincoln

DigitalCommons@University of Nebraska - Lincoln

Periphyton responses to nutrient and atrazine mixtures introduced through agricultural runoff

Justin N. Murdock

Tennessee Technological University, jnmurdock@tntech.edu

F. Douglas Shields Jr.

USDA-ARS

Richard E. Lizotte Jr.

USDA-ARS

Follow this and additional works at: https://digitalcommons.unl.edu/usdaarsfacpub

Murdock, Justin N.; Shields, F. Douglas Jr.; and Lizotte, Richard E. Jr., "Periphyton responses to nutrient and atrazine mixtures introduced through agricultural runoff" (2013). Publications from USDA-ARS / UNL Faculty. 1289.

https://digitalcommons.unl.edu/usdaarsfacpub/1289

This Article is brought to you for free and open access by the U.S. Department of Agriculture: Agricultural Research Service, Lincoln, Nebraska at DigitalCommons@University of Nebraska - Lincoln. It has been accepted for inclusion in Publications from USDA-ARS / UNL Faculty by an authorized administrator of DigitalCommons@University of Nebraska - Lincoln. 


\title{
Periphyton responses to nutrient and atrazine mixtures introduced through agricultural runoff
}

\author{
Justin N. Murdock • F. Douglas Shields Jr. • \\ Richard E. Lizotte Jr.
}

This article is a U.S. government work, and is not subject to copyright in the United States.

Accepted: 3 November 2012/Published online: 18 November 2012

(C) Springer Science+Business Media New York (outside the USA) 2012

\begin{abstract}
Agricultural runoff often contains pollutants with antagonistic impacts. The individual influence of nutrients and atrazine on periphyton has been extensively studied, but their impact when introduced together and with multiple agricultural pollutants is less clear. We simulated a field-scale runoff pulse into a riverine wetland that mimicked pollutant composition typical of field runoff of the Mississippi River Alluvial Plain. Periphyton biomass and functional responses were measured for 2 weeks along a $500 \mathrm{~m}$ section. Additionally, laboratory chamber assays were used to identify potential periphyton changes due to nutrients, atrazine, and their interactions. Generally, nutrients stimulated, and atrazine reduced chlorophyll $a(\mathrm{Chl} a)$ in chambers. In the wetland, nutrient and atrazine relationships with periphyton were weaker, and when found, were often opposite of trends in chambers. Total nitrogen (TN) was inversely related to $\mathrm{Chl} a$, and total phosphorus was inversely related to respiration $(\mathrm{R})$ rates. Atrazine (10-20 $\mu \mathrm{g} \mathrm{L}^{-1}$ in the wetland) had a positive relationship with ash-free dry mass (AFDM), and weakened the relationship between TN and AFDM. Wetland periphyton biomass was better correlated to total suspended solids than nutrients or atrazine. Periphyton function was resilient as periphyton gross primary production (GPP)/R ratios were not strongly impacted by runoff. However, whole-system GPP and R decreased over the 2-week period, suggesting that although periphyton metabolism recovered quickly,
\end{abstract}

J. N. Murdock · F. D. Shields Jr. · R. E. Lizotte Jr. USDA-Agricultural Research Service, National Sedimentation Laboratory, Oxford, MS 38655, USA

J. N. Murdock $(\bowtie)$

Department of Biology, Tennessee Technological University, PO Box 5063, Cookeville, TN 38501, USA

e-mail: jnmurdock@tntech.edu whole-system metabolism took longer to recover. The individual and combined impacts of nutrients and atrazine in complex pollutant mixtures can vary substantially from their influence when introduced separately, and non-linear impacts can occur with distance downstream of the pollutant introduction point.

Keywords Algae $\cdot$ Agricultural runoff $\cdot$ Herbicide . Metabolism · Pulse $\cdot$ Wetland

\section{Introduction}

The impact of agricultural runoff on periphyton is difficult to predict. Knowledge of how periphyton responds to runoff is critical to understanding and predicting agriculture's influence at the whole-system level as periphyton often regulates primary production, nutrient cycling, and pollution remediation in shallow aquatic systems (Bott 1996; Dodds 2003; Hill et al. 2010). Agricultural runoff contains a mixture of many chemicals. Pollutant impacts on aquatic biota can be predicted by the independent action of each pollutant (Faust et al. 2003; Junghans et al. 2006), but individual pollutant impact can change when introduced in mixtures (Relyea 2009). Nutrients [mainly nitrogen $(\mathrm{N})$ and phosphorus $(\mathrm{P})]$ and herbicides are commonly used agricultural chemicals that can directly impact periphyton growth. Atrazine is one of the most widely used herbicides in the world, and frequently occurs in agricultural runoff (Solomon et al. 1996). Individually, nutrients and atrazine have contrasting effects on periphyton, with nutrients typically stimulating growth and atrazine inhibiting it. It is not clear how periphyton communities respond to runoff containing these two antagonistic pollutants, which pollutant has the stronger influence on periphyton, or 
how strong the impact of nutrients and atrazine is compared to other pollutants in agricultural runoff.

Periphyton has both autotrophic and heterotrophic components. Typically, algae dominate autotrophic biomass, and bacteria and fungi dominate heterotrophic biomass. Mixtures of nutrients and atrazine should have different structural and functional effects on each component. Nutrients generally stimulate both autotrophic and heterotrophic growth directly. Nutrients can indirectly stimulate bacterial growth as increased algal growth often results in a greater release of dissolved organic carbon (C) from algal cells that bacteria can utilize for growth (Cole 1982; Roman and Sabater 1999). Since atrazine is a photosystem II inhibitor, it should predominantly affect algal photosynthesis. Atrazine's impacts on bacteria and fungi are not as clear, but atrazine can alter soil bacterial community structure (Voets et al. 1974) and be used as a N and C source to fuel bacterial growth (Mandelbaum et al. 1993; Radosevich et al. 1995; Wackett et al. 2002). Therefore nutrient and atrazine mixtures have the potential to change autotrophic/ heterotrophic biomass ratios and corresponding functional roles, such as primary production and respiration $(\mathrm{R})$ rates, which regulate both energy input into the system and water column dissolved oxygen (DO) concentrations.

Nutrient and atrazine mixtures can have varying effects on algal assemblages. Atrazine can negate nutrient stimulation. For example, atrazine (10 and $\left.100 \mu \mathrm{g} \mathrm{L}^{-1}\right)$ reduced the stimulatory effect of nutrients $\left(500 \mu \mathrm{g} \mathrm{L}^{-1} \mathrm{~N}\right)$ on N-limited wetland periphyton (Murdock and Wetzel 2012). Also, $\mathrm{P}$ additions (300 and $600 \mu \mathrm{g} \mathrm{L}^{-1}$ ) did not reduce the toxic effect of atrazine $\left(100 \mu \mathrm{g} \mathrm{L}^{-1}\right)$ on benthic algae from a P-limited stream (Guasch et al. 2007). Atrazine can also have little impact on algal nutrient use. Atrazine (25 $\left.\mu \mathrm{g} \mathrm{L}^{-1}\right)$ and nutrient $\left(140 \mu \mathrm{g} \mathrm{L}^{-1} \mathrm{~N}, 96 \mu \mathrm{g} \mathrm{L}^{-1} \mathrm{P}\right)$ mixture additions had the same impact on algal biomass and composition as nutrients alone on estuarine phytoplankton (Pinckney et al. 2002). More complex interactions between nutrients and atrazine are also found as some algal species are more impacted than others. For instance, in a freshwater wetland, green algal biomass decreased with atrazine $\left(0.1,1\right.$, and $\left.10 \mu \mathrm{g} \mathrm{L}^{-1}\right)$, while cyanobacteria were more tolerant of atrazine with an increasing $\mathrm{P}$ supply (up to $200 \mu \mathrm{g} \mathrm{L}^{-1}$ ) (Pannard et al. 2009).

Atrazine's direct impact on algae at the cellular level has been well studied. It reduces photosynthetic efficiency by blocking electron transport in photosystem II, thus primarily reducing energy needed for carbohydrate synthesis (Shabana 1987; DeLorenzo et al. 2004; Weiner et al. 2007). However, atrazine's influence at the community level can range from inhibition (Guasch et al. 2007), to no effect (Jurgensen and Hoagland 1990), to direct (Shabana 1987) and indirect (Rohr et al. 2008) growth stimulation. This complex response can depend on many factors. Algal species can have varying levels of susceptibility (Guasch et al. 1998; Tang et al. 1998; Lockert et al. 2006; Murdock and Wetzel 2012), higher light intensity can make algae more susceptible (Guasch et al. 1997, 2003; Guasch and Sabater 1998), and previous exposure can lessen the negative impacts of future exposures (Knauert et al. 2008; Tlili et al. 2011). Further complicating the ability to predict periphyton community response to runoff is that atrazine concentrations are often not uniform in space or time (Kolpin and Kalkhoff 1993; Solomon et al. 1996), and atrazine binding within photosystem II is reversible, with chloroplast functional recovery possible within hours of atrazine removal (Day 1993).

In this study, we simulated a runoff event into a riverine wetland to assess how periphyton responds to nutrients (a growth stimulator) and atrazine (an autotrophic growth inhibitor) within a complex runoff mixtures originating from agricultural fields. Simulated runoff was amended to mimic pollutant composition and concentrations of agricultural runoff typical of the Mississippi River Alluvial Plain (Shields and Pearce 2010). We also conducted a laboratory chamber study to help isolate the direct and interactive impacts of nutrient and atrazine on periphyton, assess the magnitude of potential effects, and highlight trends in periphyton structure and function to look for in the wetland. Study objectives were to (1) assess if nutrients and atrazine interact to change periphyton response, (2) determine whether nutrients or atrazine is more influential, and (3) measure how periphyton structure and function is altered by nutrients and atrazine within typical agricultural runoff (i.e., within a realistic multi-pollutant mixture).

\section{Methods}

\section{Study site}

A severed riverine meander bend ( $\sim 2.5 \mathrm{~km}$ long $\times 40 \mathrm{~m}$ wide) within a reach of the Coldwater River in Tunica County, Mississippi $\left(34^{\circ} 40^{\prime} 04.93^{\prime \prime} \mathrm{N}, 90^{\circ} 13^{\prime} 38.09^{\prime \prime} \mathrm{W}\right)$ was selected for this study (Fig. 1). The site, inside the flood control levee, is the result of a $0.4 \mathrm{~km}$ cutoff constructed in 1941-1942. Land-use both inside and outside the bend are in row-crop cultivation, and a buffer of natural riparian vegetation 5-100 $\mathrm{m}$ wide occurs on both banks. The site receives runoff from $\sim 100$ ha of cultivated land, primarily through an intermittent slough connected to a series of drainage ditches and gullies that drain adjacent cropland. In fall of 2006, the site was modified with the construction of two water control weirs, creating a larger, deeper cell managed as a lake-type aquatic habitat and a smaller, shallower cell, $500 \mathrm{~m}$ long, $20 \mathrm{~m}$ wide, managed as a riverine wetland (Shields and Pearce 2010; Shields et al. 


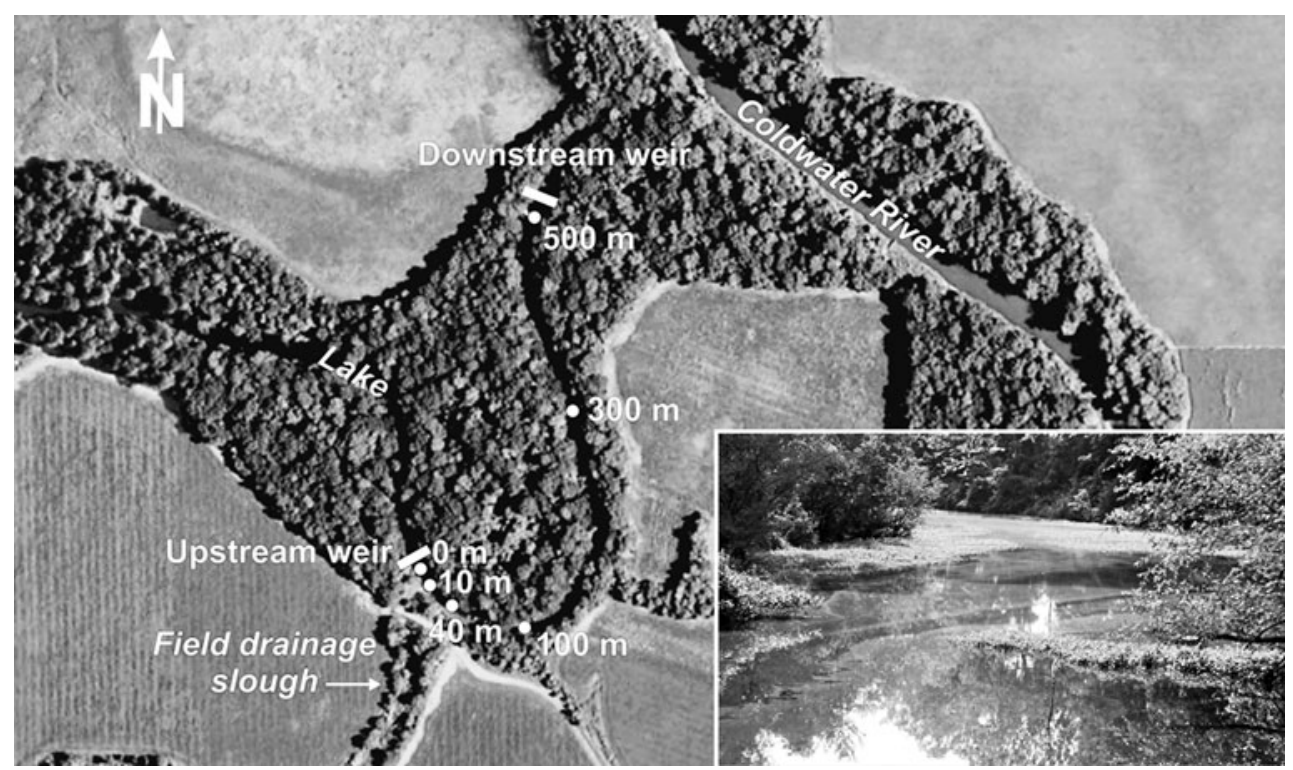

Fig. 1 Aerial photograph of the study site, Tunica County, Mississippi. The wetland lies in the lower section of the cutoff channel between the upper and lower weirs and contains the marked sites. The lake section above the upstream weir supplied the water for the

2012). The weir controlling the lake cell was located such that most runoff from adjacent fields is diverted into the wetland cell. The wetland had a mean water depth of $28 \mathrm{~cm}$, and water depth generally increased downstream. Riparian trees heavily shaded wetland margins. Water levels in the wetland rose and fell in response to runoff events and backwater flooding from the river, but neither occurred during this study. During 2005-2010, the wetland became completely dry during extended droughts in summer and fall. Weekly grab samples collected when water was present during 2006-2010 indicated relatively high suspended sediment and eutrophic conditions typical of the Mississippi Alluvial Plain region. Mean suspended sediment, total $\mathrm{P}$ and total $\mathrm{N}$ concentrations during the JuneNovember dry season were 132, 0.47 and $3.05 \mathrm{mg} \mathrm{L}^{-1}$, respectively (Shields et al. 2012). Past herbicide concentrations for this site are unavailable, but Rebich (2001) found maximum atrazine and metolachlor concentrations in runoff of 168 and $376 \mu \mathrm{g} / \mathrm{L}$, respectively at nine sites in this region from 1996 to 1999.

\section{Wetland runoff simulation}

On 24 June, 2009, $611 \mathrm{~m}^{3}$ of water was released from the upstream lake cell portion into the modified wetland cell over $\sim 4 \mathrm{~h}$, simulating agricultural runoff during a $1-\mathrm{cm}$ rainfall event from a 16-ha cultivated field. Lake water was amended with sediment from an adjacent field, phosphorus $\left(42 \% \mathrm{P}_{2} \mathrm{O}_{5}\right)$, nitrogen $\left(34 \% \mathrm{NH}_{4} \mathrm{NO}_{3}\right)$, and the pesticides atrazine, metolachlor and permethrin simulating a "first simulated runoff study. Sampling stations are marked with circles. The field drainage slough south of the 0 and $10 \mathrm{~m}$ sites is the largest source of natural runoff into the wetland. The inset photo is looking downstream from the $0 \mathrm{~m}$ site

flush" event. Metolachlor is a protein synthesis and long chain-fatty acid inhibitor and affects algal growth by impeding cell division. Permethrin is a neural toxin and acts by modifying the normal biochemistry and physiology of nerve membrane sodium channels. Little direct impact of permethrin on periphyton is expected, but it may indirectly affect periphyton by reducing invertebrates that consume periphyton. A total of $270.8 \mathrm{~kg}$ sediment, $3.6 \mathrm{~kg}$ $\mathrm{P}_{2} \mathrm{O}_{5}, 6.1 \mathrm{~kg} \mathrm{NH}_{4} \mathrm{NO}_{3}, 6,600 \mathrm{mg}$ a.i. atrazine $+5,220 \mathrm{mg}$ a.i. $S$-metolachlor (Bicep II Magnum ${ }^{\circledR}$ ), and $630.4 \mathrm{mg}$ a.i. permethrin (Hi Yield $38^{\circledR}$ ) were injected into the wetland at the upstream weir for the first $1.3 \mathrm{~h}$. The hydrograph for the event was designed by scaling an observed hydrograph from the tributary slough that entered the wetland just below the upper weir. Peak runoff flow $\left(\sim 90 \mathrm{~L} \mathrm{~s}^{-1}\right)$ was equal to the maximum discharge that could be obtained by releasing water from the lake cell through the drainage structure. Flow rates were continuously recorded by measuring the depth of flow through the drainage structure and converting flow depth to discharge using a rating curve provided by the manufacturer. Flow rates were verified using acoustic (ISCO 2150 Area Velocity Flow Module, Teledyne ISCO, Lincoln, NE, USA) and electromagnetic (Marsh McBirney Model 2000 Flow Meter, MarshMcBirney, Inc., Frederick, MD, USA) devices in the discharge channel. Outflow from the wetland was monitored using a HOBO $\mathrm{U} 20^{\mathrm{TM}}$ logging pressure transducer (Onset Computer Corporation, Bourne, MA, USA) to record the depth of flow over the weir. Target suspended sediment concentrations were set equal to the maximum observed 
June suspended sediment concentration in the slough tributary $\left(325 \mathrm{mg} \mathrm{L}^{-1}\right)$. Five sample stations were established relative to the runoff inflow location; $10,40,100,300$, and $500 \mathrm{~m}$ downstream (Fig. 1). Further details of the runoff simulation are presented in Lizotte et al. (2012a) and Kröger et al. (2012). An additional pressure transducer placed at the $10 \mathrm{~m}$ station recorded water levels at $20 \mathrm{~min}$ intervals for the duration of the study. Water depth at each station was estimated by combining water stage hydrographs with a bathymetric survey of the wetland.

\section{Water quality}

Water samples $(1 \mathrm{~L})$ were collected every $30 \mathrm{~min}$ within the first $4 \mathrm{~h}$; every $4 \mathrm{~h}$ until $48 \mathrm{~h}$; and on days 5, 7, 14, and 21, at each site. Automated pumping samplers (ISCO Model 3700 , Teledyne ISCO, Lincoln, NE, USA) were used to collect samples during the first $48 \mathrm{~h}$. Sample collection at $100 \mathrm{~m}$ was modified due to drying at this site caused by a $0.2 \mathrm{~m}$ increase in elevation from long-term sediment accumulation in the channel. As a result, data from $100 \mathrm{~m}$ were excluded from analyses. Samples were placed on ice, transported to the USDA-ARS National Sedimentation Laboratory (NSL), and stored at $4{ }^{\circ} \mathrm{C}$ (typically $<24 \mathrm{~h}$ ). Samples collected after $24 \mathrm{~h}$ were in $1 \mathrm{~L}$ glass jars fitted with a Teflon lined screw cap and treated as previously described.

Analyses for suspended solids, N, and P were conducted according to (APHA 2005). Total suspended solids (TSS) were dried at $180{ }^{\circ} \mathrm{C}$ and weighed. Dissolved $\mathrm{N}$ and $\mathrm{P}$ samples were filtered through a $45 \mu \mathrm{m}$ cellulose $\mathrm{NO}_{3}$ filter and analyzed with colorimetric methods. $\mathrm{PO}_{4}-\mathrm{P}$ was analyzed using the ascorbic acid method; $\mathrm{NH}_{4}-\mathrm{N}$ the phenate method; $\mathrm{NO}_{3}-\mathrm{N}$ the cadmium reduction method; and $\mathrm{NO}_{2}-\mathrm{N}$ the sulfanilamide method. TP samples were digested with persulfate and analyzed as $\mathrm{PO}_{4}-\mathrm{P}$. Total Kjeldahl nitrogen (TKN) was analyzed using block digestions and automated colorimetry. Total nitrogen (TN) was calculated by adding together $\mathrm{NO}_{3}-\mathrm{N}, \mathrm{NO}_{2}-\mathrm{N}$, and TKN. Colorimetric analyses were performed using a ThermoSpectronic Genesys $^{\text {TM }} 10$ ultraviolet (UV) spectrophotometer (Spectronic Instruments, Inc., Rochester, NY, USA).

Pesticide analyses were conducted according to (Smith et al. 2007). Briefly, pesticides from unfiltered water samples were extracted using pesticide-grade ethyl acetate, dried over anhydrous $\mathrm{Na}_{2} \mathrm{SO}_{4}$ and concentrated to near dryness by rotary evaporation. The extract was then subjected to silica gel column chromatography cleanup, and concentration to $1 \mathrm{~mL}$ volume under $99.9 \%$ dry nitrogen for GC analysis. Two Agilent HP model 6890 gas chromatographs (Agilent Technologies, Inc., Waldbronn, Germany) equipped with dual Agilent HP 7683 ALS autoinjectors, dual split-splitless inlets, dual capillary columns, an Agilent HP Kayak XA Chemstation, and the autoinjector set at $1.0 \mu \mathrm{L}$ injection volume fast mode were used for all targeted pesticide analyses. Atrazine and metolachlor have low sorption capacities to sediments $\left(\log \mathrm{P}_{\mathrm{ow}}\right.$ octanol-water partition coefficients of 2.3 for atrazine and 3.4 for metolachlor: see Zheng and Cooper 1996; Gao et al. 1998; Lima et al. 2010; Lizotte et al. $2012 b$ ). Herbicides were not pre-sorbed to the sediment as sediment and herbicides were added simultaneously, but independently. Therefore both pesticides need more than $24 \mathrm{~h}$ to fully sorb to suspended sediment, which allowed $>80 \%$ of the measured herbicide concentrations to be biologically active during the first 2 days. In addition, the majority of added sediments settled out the water column within 24-48 h. This settling further decreased the likelihood that the measured herbicide concentrations in the water column samples were directly associated with sediment bound herbicide.

Temperature and DO were measured in situ from June 16, 2009 through July 22, 2009 at each station using Yellow Springs Instruments 6920 V2 data logging sondes (YSI, Inc., Yellow Springs, Ohio, USA). Measurements were collected hourly during pre-treatment days -7 to -3 , and post-treatment days $0-5,7-11$, and 14-19. On two occasions, measurements were not recorded due to equipment failure.

\section{Periphyton}

Six racks of $7 \times 15 \mathrm{~cm}$ unglazed clay tiles (20 tiles per rack) were deployed at each site from 26 May to 24 June, 2009 (4 weeks). Periphyton structure [algal (autotrophic) biomass as chlorophyll $a(\mathrm{Chl} a)$, ash-free dry mass (AFDM, a measure of both autotrophic and heterotrophic biomass)] and function [gross primary production (GPP), $\mathrm{R}$, and ammonium $\left(\mathrm{NH}_{4}{ }^{+}\right)$uptake rates] were measured on tiles at each location on days 0 (just prior to the release), 2 , 7, and 14. At each sample date, tiles from each station were randomly collected without replacement and returned to the NSL within $1.5 \mathrm{~h}$, in sealed, moist containers. All three tiles from each site were placed in a $7.5 \mathrm{~L}$ clear plastic chamber (\#295-C, Pioneer Plastics Inc., Dixon, KY, USA), along with a water only chamber. Chambers were filled with water from the 10-m site filtered through $250 \mu \mathrm{m}$ mesh to remove periphyton consumers and large particles. Water was gently circulated with a small submersible pump placed inside each chamber. Chambers were set up outdoors under a $65 \%$ shade cloth.

Periphyton net primary productivity (NPP) and R were measured by recording changes in DO every $15 \mathrm{~min}$ for $1.5 \mathrm{~h}$ in the light, and dark (covered with black plastic), respectively. Chambers were completely filled with water and sealed with a clear lid, with care taken to exclude air bubbles. DO was measured with a YSI 55 DO meter inserted through a hole in the top of each chamber. $\mathrm{R}$ and 
NPP were calculated as the slope of the DO concentration change over time per total surface area of the tiles, and adjusted to $\mathrm{g} \mathrm{O}_{2} \mathrm{~m}^{-2} \mathrm{~h}^{-1}$ during dark and light periods, respectively (Bott 2006). GPP was calculated as NPP + R. $\mathrm{R}$ and GPP rates were temperature corrected to $20{ }^{\circ} \mathrm{C}$ (Naegeli and Uehlinger 1997) due to differences in water temperature among sampling dates. $\mathrm{NH}_{4}{ }^{+}$uptake potential was used as an indicator of the periphyton nutrient demand, and was measured immediately following metabolism. Water $(0.5 \mathrm{~L})$ was removed from each chamber and a $\mathrm{NH}_{4}{ }^{+}$spike was added to raise water concentrations $20 \mu \mathrm{g} \mathrm{L}^{-1}$. Filtered water samples were collected every $15 \mathrm{~min}$ for $1 \mathrm{~h}$ and frozen until analysis using the indophenol blue method (APHA 2005). $\mathrm{NH}_{4}{ }^{+}$uptake rates were calculated from the slope of the natural log transformed $\mathrm{NH}_{4}{ }^{+}$concentration versus time and adjusted to $\mu \mathrm{g}$ $\mathrm{NH}_{4}^{+} \mathrm{m}^{-2} \mathrm{~h}^{-1}$ (O'Brien et al. 2007).

Each tile was sampled for AFDM and Chl $a$ following functional measurements. AFDM was collected by scraping a portion of the tile with a razor. Scrapings were filtered onto a pre-weighed glass fiber filter, dried at $60{ }^{\circ} \mathrm{C}$ for $24 \mathrm{~h}$, and then ashed at $500{ }^{\circ} \mathrm{C}$ for $1 \mathrm{~h}$ (Steinman et al. 2006). The tile with remaining periphyton was frozen until analyzed for Chl $a$. The non-scraped section of the tile was submerged in an autoclavable bag in $95 \% \mathrm{EtOH}$. Bags were put in a $78{ }^{\circ} \mathrm{C}$ water bath for $5 \mathrm{~min}$, and extracted in the dark for $12 \mathrm{~h}$ (Sartory and Grobbelaar 1984). Chl $a$ was measured with a spectrophotometer, corrected for phaeophytin, and calculated as $\mathrm{mg} \mathrm{Chl} a \mathrm{~cm}^{-2}$. The Chl a/AFDM ratio was calculated to assess relative changes in autotrophic and heterotrophic periphyton biomass.

Sonde data was used to estimate whole-system GPP, R, and aeration $\left(\mathrm{k} \mathrm{min}^{-1}\right)$ rates at each station. Rates were calculated by fitting modeled daily DO to measured daily DO at each station (Dodds et al. 2008; Riley 2011). The "solver" function in Microsoft Excel was used to vary alpha, R, and aeration to minimize the average sum of squares of the difference between observed and modeled DO concentration over time. The model used light data from the nearby USDA Goodwin Creek weather station (ftp://ftp.srrb.noaa.gov/ pub/data/surfrad/Goodwin_Creek_MS/) to fit R, aeration, and the initial increase in photosynthetic rate, alpha (Jassby and Platt 1976). It was assumed that light intensity was never saturating wetland photosynthesis as water column oxygen concentrations consistently continued to increase during periods of maximum surface light intensity (data not shown). All rates are a function of temperature (Naegeli and Uehlinger 1997).

\section{Laboratory experiment}

Thirty $7 \times 7 \mathrm{~cm}$ unglazed clay tiles were incubated in the lake cell, just above the upstream weir from 23 June to 14
July, 2009 (4 weeks). Tiles were returned to the lab in dark, sealed plastic containers. Within $2 \mathrm{~h}$ of collection, single tiles were placed in individual $1.95 \mathrm{~L}$ round plastic containers (\#185-C, Pioneer Plastics Inc., Dixon, KY, USA), which were filled with $1.6 \mathrm{~L}$ of atrazine-free spring water collected from the University of Mississippi Field Station. Water was filtered through $250 \mu \mathrm{m}$ mesh to remove large grazers. Six atrazine and nutrient treatments and a water only treatment were established with five replicates per treatment. Treatments were nutrients only (NUT; $500 \mu \mathrm{g} \mathrm{L}^{-1} \mathrm{NO}_{3}-\mathrm{N}, 31 \mu \mathrm{g} \mathrm{L}^{-1} \mathrm{PO}_{4}-\mathrm{P}$ ), low atrazine (LA; $10 \mu \mathrm{g} \mathrm{L}^{-1}$, added as Atrazine $4 \mathrm{~F}^{\circledR}$, Tenkoz, Inc., Alpharette, GA, USA), high atrazine (HA; $100 \mu \mathrm{g} \mathrm{L}^{-1}$ ), nutrients plus low atrazine (NLA), nutrients plus high atrazine (NHA), and a spring water only control (CON). The high atrazine concentration was based on the maximum atrazine concentration in the wetland study release pulse and the low concentration was based on typical levels found in the Mississippi River Basin (Pratt et al. 1997; Solomon et al. 1996). Due to potential adsorption of nutrients and atrazine on sediment, TSS was not used. This experiment was used as a worst case impact to identify trends in algal response following exposure to nutrients, atrazine, and their mixture. All chambers were placed in an incubator at $23{ }^{\circ} \mathrm{C}$ and 16:8 h light:dark cycle for 20 days. Light intensity was $\sim 90 \mu \mathrm{mol}$ quanta $\mathrm{m}^{-2} \mathrm{~s}^{-1}$. Chamber water was replaced with filtered spring water on days 3 and 9 , and treatment condition reestablished with appropriate nutrient and atrazine concentrations during water replacement. Removed water was analyzed for dissolved and total $\mathrm{N}$ and $\mathrm{P}$, and atrazine as described earlier.

Periphyton NPP, $\mathrm{R}$, and $\mathrm{NH}_{4}{ }^{+}$uptake rates were measured in each chamber on days $0,2,8$, and 19 using chamber methods described previously. Differences in the lab study were that chambers were $1.95 \mathrm{~L}$ (total volume), a magnetic stir bar and stir plate was used to provide water movement (velocity of $\sim 15 \mathrm{~cm} \mathrm{~s}^{-1}$ ) and fluorescent lights were used for NPP measurements. In addition to tile Chl $a$, chamber wall Chl $a$ was also measured on day 20. After tile and water removal, the entire chamber wall was scraped with a razor and algae filtered onto a $45 \mu \mathrm{m}$ pore size glass fiber filter. Chamber wall surface area was calculated and wall algae calculated as $\mathrm{mg} \mathrm{Chl} a \mathrm{~m}^{-2}$.

Data analysis

\section{Wetland}

Chl $a$ and AFDM effect sizes (standardized mean differences) were used to compare changes in periphyton biomass to allow for differences in starting periphyton communities along the length of the wetland. Due to small sample sizes, effect sizes were calculated as Cohen's $d$ 
values using pooled standard deviations (Dunlop et al. 1996). An effect size greater than 0.5 suggests a large effect (Cohen 1988). Multiple regression analysis was used to test the influence of nutrients and atrazine on periphyton structure (Chl $a, \mathrm{AFDM}$ ) and function (GPP, R, and $\mathrm{NH}_{4}{ }^{+}$ uptake). The model used was

$$
\begin{aligned}
\text { Response variable }= & \text { intercept }+ \text { atrazine }+ \text { metolachlor } \\
& +\mathrm{TSS}+\mathrm{TN}+\mathrm{TP}+\mathrm{Day}+\text { atrazine } \\
& \times \mathrm{TN}+\text { atrazine } \times \mathrm{TP}+\text { error }
\end{aligned}
$$

Independent variables were $\mathrm{TN}, \mathrm{TP}$, atrazine, metolachlor, TSS, and cross product terms for atrazine, TN, and TP to assess if nutrients and atrazine interacted to produce a nonlinear periphyton response. At each sample time, pollutant values were calculated as time-weighted mean concentrations to incorporate temporal exposure to the pulsed runoff event. A time variable (day) was also included to assess temporal relationships among pollutants and periphyton. Regression models were evaluated using Akaike Information Criterion adjusted for small sample sizes $\left(\mathrm{AIC}_{\mathrm{c}}\right)$. Akaike weights $\left(w_{i}\right)$ were calculated for all candidate models. $w_{i}$ can be interpreted as the weight of evidence that model $i$ is the best approximating model, given the data and all candidate models (Burnham and Anderson 1998). The relative importance factor for each independent variable was also calculated. Statistical tests were done with JMP version 9.0 (SAS, Inc., Cary, NC. USA).

\section{Laboratory chambers}

Temporal trends in tile GPP, $\mathrm{R}$, and $\mathrm{NH}_{4}{ }^{+}$uptake were compared using two-way repeated measure multivariate analysis of variance (MANOVA). Factors were nutrients (two levels: unaltered or added nutrients), and atrazine (three levels: 0,10 , and $100 \mu \mathrm{g} \mathrm{L}^{-1}$ ). Day 20 structural (tile, wall, and total chamber $\mathrm{Chl} a$ ) and functional (GPP, $\mathrm{R}, \mathrm{NH}_{4}{ }^{+}$uptake) differences were analyzed with two-way analysis of variance (ANOVA) and Tukey post hoc comparisons to assess treatment differences. Data were natural $\log$ transformed as needed to meet homoscedasticity requirements prior to analysis. Alpha was set at 0.05 in all analyses.

\section{Results}

Wetland runoff simulation

\section{Hydrology and water quality}

Peak discharge $\left(87 \mathrm{~L} \mathrm{~s}^{-1}\right)$ occurred $1.3 \mathrm{~h}$ into the release and slowly declined over a $3 \mathrm{~h}$ period (Fig. 2a). All water was retained in the wetland, as no water overtopped the downstream weir. The timing of the water pulse through the wetland was well represented by atrazine concentrations. The atrazine peak arrived at 1.5, 1.5, 2, and $48 \mathrm{~h}$ from the start of the release at the 10, 40,300, and $500 \mathrm{~m}$ respectively (Fig. 2b). A lower magnitude and wider peak at $500 \mathrm{~m}$ shows a large time lag and runoff dilution between 300 and $500 \mathrm{~m}$.

Prior to the release, TP ranged from 1 to $3.4 \mathrm{mg} \mathrm{L}^{-1}$; $\mathrm{PO}_{4}-\mathrm{P}$ ranged from $<20$ to $160 \mu \mathrm{g} \mathrm{L}^{-1}$; TN ranged from 2 to $6.7 \mathrm{mg} \mathrm{L}^{-1} ; \mathrm{NH}_{4}{ }^{+}-\mathrm{N}$ was $<20 \mu \mathrm{g} \mathrm{L}^{-1} ; \mathrm{NO}_{3}{ }^{-}-\mathrm{N}$ ranged
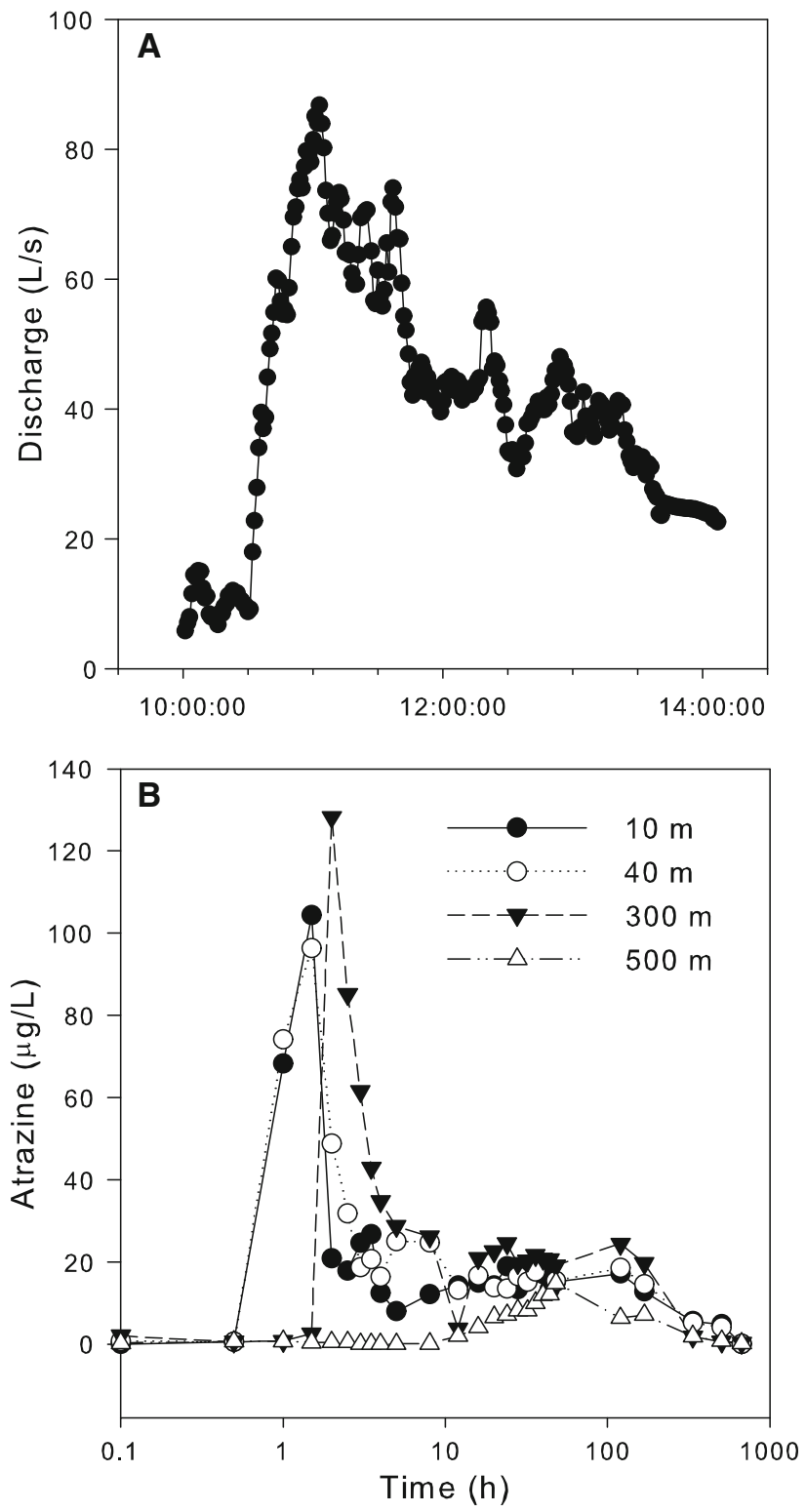

Fig. 2 a Hydrograph of water released from the upper lake cell into the wetland on 24, June 2009. b Atrazine concentration at each station showing time runoff pulse reached each station, and decreasing pulse amplitude between 300 and $500 \mathrm{~m}$ 
from 30 to $50 \mu \mathrm{g} \mathrm{L}^{-1}$, and $\mathrm{NO}_{2}{ }^{-}-\mathrm{N}$ was $<20 \mu \mathrm{g} \mathrm{L}{ }^{-1}$. Atrazine, metolachlor, and permethrin were below detection limits $\left(1 \mu \mathrm{g} \mathrm{L}^{-1}\right.$ for atrazine, $0.1 \mu \mathrm{g} \mathrm{L}^{-1}$ for metolachlor and permethrin). Time-weighted and maximum nutrient, pesticide, and suspended sediment concentrations for each station and sampling day are presented in Table 1. Maximum atrazine, metolachlor, and permethrin concentrations at $500 \mathrm{~m}$ averaged 86, 86, and $92 \%$ less, respectively, than at $10 \mathrm{~m}$. Maximum TN and TP concentrations gradually decreased from 10 to $500 \mathrm{~m}$, declining 62 and $29 \%$, respectively (Table 1). A sharp decline in pesticides, $\mathrm{NH}_{4}{ }^{+}, \mathrm{PO}_{4}{ }^{-}$, and TSS was observed between 300 and $500 \mathrm{~m} . \mathrm{NO}_{3}{ }^{-}$and $\mathrm{NO}_{2}{ }^{-}$increased with distance, increasing 88 and $93 \%$ by $500 \mathrm{~m}$, respectively.

\section{Periphyton structure}

Starting periphyton biomass on tiles was different among stations. Following the release, the greatest changes in structure occurred at 10 and $40 \mathrm{~m}$, and there was substantial temporal and longitudinal variability along the $500 \mathrm{~m}$ wetland.

At $10 \mathrm{~m}$, tile Chl $a$ decreased $55 \%$ by day 2 (effect size $=-3.1$ ) and $87 \%$ by day 7 (effect size $=-5.6$, Table 2). Conversely, by day $2 \mathrm{Chl} a$ increased $33 \%$ at $40 \mathrm{~m}$ (effect size $=1.0$ ) and $12 \%$ at $300 \mathrm{~m}$ (effect size $=1.1$, but then declined over time. Chl $a$ effect sizes were weakest at $500 \mathrm{~m}$, with effect sizes of $-1.3,-0.4$, and 0.1 on days 2,7 , and 14 , respectively (Table 2). TSS,

Table 1 Time weighted average pesticide, nutrient and suspended sediment concentrations $\left(\mu \mathrm{g} \mathrm{L}{ }^{-1}\right)$ in the wetland for initial conditions (day 0 ), and days 2, 7, and 14

\begin{tabular}{|c|c|c|c|c|c|c|c|c|c|c|c|}
\hline Days & $\begin{array}{l}\text { Distance } \\
\text { from release } \\
\text { (m) }\end{array}$ & $\begin{array}{l}\text { Atrazine } \\
\left(\mu \mathrm{g} \mathrm{L}^{-1}\right)\end{array}$ & $\begin{array}{l}\text { Metolachlor } \\
\left(\mu \mathrm{g} \mathrm{L}^{-1}\right)\end{array}$ & $\begin{array}{l}\text { Permethrin } \\
\left(\mu \mathrm{g} \mathrm{L}^{-1}\right)\end{array}$ & $\begin{array}{l}\mathrm{NH}_{4}-\mathrm{N} \\
\left(\mu \mathrm{g} \mathrm{L}^{-1}\right)\end{array}$ & $\begin{array}{l}\mathrm{NO}_{2}-\mathrm{N} \\
\left(\mu \mathrm{g} \mathrm{L}^{-1}\right)\end{array}$ & $\begin{array}{l}\mathrm{NO}_{3}-\mathrm{N} \\
\left(\mu \mathrm{g} \mathrm{L}^{-1}\right)\end{array}$ & $\begin{array}{l}\text { SRP } \\
\left(\mu \mathrm{g} \mathrm{L}^{-1}\right)\end{array}$ & $\begin{array}{l}\mathrm{TN} \\
\left(\mathrm{mg} \mathrm{L}^{-1}\right)\end{array}$ & $\begin{array}{l}\mathrm{TP} \\
\left(\mathrm{mg} \mathrm{L}^{-1}\right)\end{array}$ & $\begin{array}{l}\mathrm{TSS} \\
\left(\mathrm{mg} \mathrm{L}^{-1}\right)\end{array}$ \\
\hline
\end{tabular}

Time weighted mean concentrations

\begin{tabular}{|c|c|c|c|c|c|c|c|c|c|c|c|}
\hline \multirow[t]{5}{*}{0} & Lake & $\mathrm{BD}$ & 0.2 & 0.1 & 23.5 & 7.5 & 51.0 & 249 & 2.1 & 0.9 & 96 \\
\hline & 10 & 0.0 & BD & 0.3 & 56.0 & 9.0 & 42.0 & 0 & 6.7 & 3.8 & 1,419 \\
\hline & 40 & BD & $\mathrm{BD}$ & 0.4 & 14.0 & 12.0 & 33.0 & 60 & 8.1 & 3.3 & 463 \\
\hline & 300 & 2.0 & BD & 0.2 & 62.0 & 7.0 & 27.0 & 22 & 4.5 & 3.4 & 463 \\
\hline & 500 & BD & 0.1 & 0.2 & 32.0 & 13.0 & 51.0 & 164 & 3.3 & 2.0 & 54 \\
\hline \multirow[t]{5}{*}{2} & Lake & BD & 0.2 & 0.1 & 23.5 & 7.5 & 51.0 & 249 & 2.1 & 0.9 & 96 \\
\hline & 10 & 16.9 & 7.7 & 0.9 & 63.3 & 9.6 & 32.2 & 136 & 2.8 & 2.1 & 714 \\
\hline & 40 & 18.0 & 9.7 & 0.5 & 45.6 & 9.4 & 29.0 & 183 & 2.7 & 1.8 & 329 \\
\hline & 300 & 22.1 & 12.3 & 0.3 & 94.4 & 13.4 & 61.0 & 223 & 3.0 & 2.1 & 391 \\
\hline & 500 & 7.1 & 4.6 & 0.2 & 51.6 & 13.3 & 54.0 & 240 & 2.9 & 1.8 & 92 \\
\hline \multirow[t]{5}{*}{7} & Lake & BD & 0.2 & 0.1 & 23.5 & 7.5 & 51.0 & 249 & 2.1 & 0.9 & 96 \\
\hline & 10 & 15.8 & 4.7 & 0.8 & 73.1 & 9.2 & 43.1 & 103 & 3.0 & 2.7 & 515 \\
\hline & 40 & 17.2 & 5.4 & 0.3 & 26.3 & 8.7 & 31.4 & 142 & 2.6 & 2.4 & 132 \\
\hline & 300 & 22.4 & 11.6 & 0.2 & 83.3 & 20.8 & 72.6 & 161 & 2.9 & 2.1 & 160 \\
\hline & 500 & 6.8 & 3.8 & 0.2 & 25.6 & 11.7 & 48.9 & 184 & 2.6 & 1.4 & 49 \\
\hline \multirow[t]{5}{*}{14} & Lake & $\mathrm{BD}$ & 0.2 & 0.1 & 23.5 & 7.5 & 51.0 & 249 & 2.1 & 0.9 & 96 \\
\hline & 10 & 10.7 & 3.2 & 0.5 & 66.0 & 11.1 & 54.5 & 72 & 2.9 & 2.2 & 360 \\
\hline & 40 & 11.2 & 3.4 & 0.3 & 55.7 & 9.8 & 32.2 & 91 & 2.6 & 1.7 & 89 \\
\hline & 300 & 12.1 & 6.1 & 0.2 & 85.6 & 33.9 & 135.0 & 143 & 2.7 & 1.6 & 93 \\
\hline & 500 & 4.3 & 2.1 & 0.2 & 29.8 & 30.3 & 161.0 & 162 & 2.6 & 1.3 & 70 \\
\hline \multicolumn{12}{|c|}{ Maximum observed concentrations } \\
\hline & Lake & $\mathrm{BD}$ & 0.3 & 0.1 & 24.0 & 8.0 & 54.0 & 282 & 12.0 & 2.7 & 106 \\
\hline & 10 & 104.0 & 67.7 & 6.4 & 420 & 13.0 & 85.0 & 3,124 & 10.6 & 4.1 & 5,136 \\
\hline & 40 & 96.3 & 71.9 & 10.2 & 404 & 12.0 & 121 & 3,513 & 9.3 & 4.1 & 4,722 \\
\hline & 300 & 128.0 & 100.0 & 4.5 & 411 & 111 & 1,246 & 3,001 & 7.1 & 3.8 & 3,052 \\
\hline & 500 & 14.8 & 9.8 & 0.5 & 81.0 & 108 & 1,075 & 316 & 4.0 & 2.9 & 178 \\
\hline
\end{tabular}

Lake is just above the upstream weir

$B D$ below detection limit (atrazine $=1 \mu \mathrm{g} \mathrm{L}{ }^{-1}$, metolachlor and permethrin $=0.1 \mu \mathrm{g} \mathrm{L}^{-1}$ ) 
$\mathrm{TN}$, and metolachlor had the strongest relationship with tile Chl $a$, and together explained $78 \%$ of the variation (Table 3). Surprisingly, metolachlor had a positive relationship with Chl $a$. TN had a negative relationship, corresponding to a greater decrease in tile $\mathrm{Chl} a$ at higher TN concentrations. Atrazine was included in the second best model, but this model was 3.9 times less likely to be the best approximating model. Unlike metolachlor, atrazine had a negative association with $\mathrm{Chl} a$ (relative importance value of -0.28 , Table 4 ). TSS had a higher relative importance $(-0.90)$ than metolachlor $(0.75)$ and $\mathrm{TN}$
$(-0.63)$, but all were strong explanatory variables (Tables 3,4$)$. No strong nutrient and atrazine interactions on Chl $a$ were found.

AFDM increased at all stations during the 14 days following the release, with the greatest increases at 10 and $40 \mathrm{~m}$ with a 14-day effect size of 2.1 and 4.0, respectively (Table 2). The 300 and $500 \mathrm{~m}$ sites had smaller and more variable responses than upstream sites. Day 14 AFDM effect sizes were 2.8 and 3.2 for 300 and $500 \mathrm{~m}$, respectively. The best AFDM model explained $93 \%$ of the variation and included TSS, atrazine, metolachlor, and an

Table 2 Wetland tile periphyton structure

\begin{tabular}{|c|c|c|c|c|c|c|c|c|c|c|}
\hline \multirow[t]{2}{*}{ Station } & \multirow[t]{2}{*}{ Days } & \multicolumn{3}{|l|}{ Chl $a$} & \multicolumn{3}{|l|}{ AFDM } & \multicolumn{3}{|c|}{ Chl $a$ /AFDM } \\
\hline & & Mean $\left(\mathrm{mg} \mathrm{m}^{-2}\right)$ & Std dev & Effect size & Mean $\left(\mathrm{g} \mathrm{m}^{-2}\right)$ & Std dev & Effect size & Mean & Std dev & Effect size \\
\hline \multirow[t]{4}{*}{10} & 0 & 45.9 & 10.0 & & 2.9 & 0.6 & & 15.7 & 1.8 & \\
\hline & 2 & 20.7 & 5.8 & -3.1 & 38.3 & 17.8 & 2.8 & 0.7 & 0.6 & -11.5 \\
\hline & 7 & 5.8 & 1.8 & -5.6 & 31.9 & 10.4 & 3.9 & 0.2 & 0.1 & -12.5 \\
\hline & 14 & 7.9 & 1.5 & -5.3 & 68.1 & 44.8 & 2.1 & 0.2 & 0.1 & -12.5 \\
\hline \multirow[t]{4}{*}{40} & 0 & 9.3 & 1.4 & & 6.4 & 5.6 & & 2.1 & 1.1 & \\
\hline & 2 & 13.8 & 6.0 & 1.0 & 46.1 & 31.7 & 1.7 & 0.8 & 1.1 & -1.2 \\
\hline & 7 & 12.8 & 3.0 & 1.5 & 105.6 & 88.0 & 1.6 & 0.2 & 0.1 & -2.5 \\
\hline & 14 & 6.4 & 2.4 & -1.5 & 33.7 & 7.9 & 4.0 & 0.2 & 0.1 & -2.4 \\
\hline \multirow[t]{4}{*}{300} & 0 & 28.6 & 2.2 & & 9.8 & 3.8 & & 3.3 & 1.7 & \\
\hline & 2 & 32.6 & 4.7 & 1.1 & 12.8 & 4.7 & 0.7 & 3.0 & 1.9 & -0.2 \\
\hline & 7 & 29.9 & 3.2 & 0.5 & 16.2 & 13.6 & 0.6 & 2.9 & 2.2 & -0.2 \\
\hline & 14 & 21.8 & 4.7 & -1.8 & 23.1 & 5.7 & 2.8 & 1.0 & 0.2 & -2.0 \\
\hline \multirow[t]{4}{*}{500} & 0 & 17.6 & 5.3 & & 4.2 & 2.4 & & 4.7 & 1.8 & \\
\hline & 2 & 12.4 & 2.6 & -1.3 & 11.7 & 7.6 & 1.3 & 1.4 & 0.9 & -2.3 \\
\hline & 7 & 15.7 & 3.4 & -0.4 & 11.1 & 10.2 & 0.9 & 2.9 & 2.7 & -0.8 \\
\hline & 14 & 18.2 & 4.0 & 0.1 & 18.3 & 5.7 & 3.2 & 1.0 & 0.3 & -2.8 \\
\hline
\end{tabular}

Mean, standard deviations and effect sizes $\mathrm{Chl} a, \mathrm{AFDM}$, and their ratio at each station on days 0 (pre release), 2, 7, and 14. Effect size is relative to day 0

Table 3 Best approximating models for predicting structural and functional response variables in the wetland as determined by $\mathrm{AIC}_{\mathrm{c}}$ values

\begin{tabular}{|c|c|c|c|c|c|c|}
\hline Response variable & Model parameters & Adjusted $R^{2}$ & $\mathrm{AIC}_{\mathrm{c}}$ & $\Delta_{i}$ & $w_{i}$ & K \\
\hline \multirow[t]{2}{*}{ Chl $a$ (effect size) } & TN, TSS, Met & 0.78 & 90.03 & 0.00 & 0.43 & 3 \\
\hline & TP, TSS, Atr & 0.74 & 92.70 & 2.68 & 0.11 & 3 \\
\hline \multirow[t]{3}{*}{ AFDM (effect size) } & TSS, Atr, Met, TN $\times$ Atr & 0.93 & 74.40 & 0.00 & 0.33 & 4 \\
\hline & Day, TN, TP, TSS, TN $\times$ Atr & 0.96 & 74.82 & 0.42 & 0.27 & 5 \\
\hline & TN, TSS, Atr, Met, TN $\times$ Atr & 0.95 & 76.26 & 1.86 & 0.13 & 5 \\
\hline \multirow[t]{2}{*}{ Chlorophyll/AFDM } & TSS, Atr & 0.56 & 146.26 & 0.00 & 0.12 & 2 \\
\hline & TP, TSS, Atr & 0.63 & 146.48 & 0.23 & 0.11 & 3 \\
\hline Respiration & $\mathrm{TP}, \mathrm{TP} \times$ Atr & 0.35 & -68.46 & 0.00 & 0.13 & 2 \\
\hline Gross primary productivity & TSS & 0.13 & -54.95 & 0.00 & 0.08 & 1 \\
\hline Ammonium uptake & Day & 0.28 & 231.74 & 0.00 & 0.17 & 1 \\
\hline
\end{tabular}

Intercept and error terms were also included in all models. Only models with a $w_{i} \geq 0.10$ (suggesting strong evidence of support) are presented Atr atrazine; Met metolachlor; TSS total suspended solids; TN total nitrogen; TP total phosphorus; Atr $\times T N$ and Atr $\times T P$ atrazine interaction with TN and TP, respectively; $w_{i}$ Akaike weighting; $K$ number of parameters in model; $\Delta_{i}$ difference in AICc of model from the best model 
atrazine $\times \mathrm{TN}$ interaction (Table 3 ). The second best model included nutrients (TN and TP) instead of the two herbicides, and was only 1.2 times less likely to be the better model. Both models included TSS and an atrazine $\times$ TN interaction, which had importance values of 0.85 and -0.95 , respectively (Table 4). Atrazine and metolachlor had the same relative importance, but opposite relationships with AFDM, with atrazine associated with higher AFDM. Although TN reduced AFDM and atrazine increased it, these two pollutants interacted, leading to a larger decrease in AFDM when both $\mathrm{TN}$ and atrazine were present, than with TN alone.

Chl a/AFDM ratios decreased at all sites, which corresponds to less chlorophyll per periphyton biomass, and potentially less relative autotrophic biomass. The largest ratio change occurred at $10 \mathrm{~m}(-12.5$ effect size by day 14). The best Chl a/AFDM ratio model included TSS and atrazine $\left(R^{2}=0.56\right.$, Table 3$)$. The second best model also included TP, and increased the $R^{2}$ to 0.63 . This model was only 1.09 times less likely to be the better model than the two-parameter model. Atrazine had a relative importance of -0.86 , and decreased the Chl a/AFDM ratio. TSS and $\mathrm{TP}$ had relative importance values of 0.97 and 0.29 , respectively, and were correlated with higher Chl a/AFDM ratios.

\section{Periphyton metabolism}

Prior to the release, tile periphyton GPP and $\mathrm{R}$ were greatest just below the release point at 10 and $40 \mathrm{~m}$, and $\mathrm{NH}_{4}{ }^{+}$uptake rates were similar among stations (Fig. 3). There was high variability in functional response along the wetland following the runoff simulation. $\mathrm{R}$ consistently declined at 10 and $40 \mathrm{~m}$, but increased at $300 \mathrm{~m}$. GPP decreased at $10 \mathrm{~m}$, but increased at $300 \mathrm{~m}$. $\mathrm{NH}_{4}{ }^{+}$uptake tended to decrease over time at all stations.
Periphyton function was not as well predicted as periphyton structure. Thirty-five percent of periphyton $\mathrm{R}$ variation was explained by $\mathrm{TP}$ and an atrazine $\times \mathrm{TP}$ interaction (Table 3). TP was inversely related to $\mathrm{R}$ and had a relative importance of -0.55 (Table 4). Atrazine partially mitigated the negative TP and R relationship. The best GPP model included TSS alone and explained only $13 \%$ of the variation. TSS had a relative importance factor of $0.40 . \mathrm{NH}_{4}{ }^{+}$uptake decreased over time and was more related to time since the release than nutrients or atrazine. Day explained $28 \%$ of the variation and had a relative importance of 0.75 .

During the 18 days following the release, whole-system GPP and R generally decreased at all stations (Fig. 4). Within this larger trend, however, were smaller, transient variations. At $10 \mathrm{~m}$ and $40 \mathrm{~m}$, both GPP and R decreased directly after the release, had a sharp increase for 2-3 days, and then slowly declined. At $300 \mathrm{~m}$, a small increase in GPP and R occurred during the first 2-3 days followed by a decline in both. $500 \mathrm{~m}$ had only a gradual decrease in GPP and $\mathrm{R}$ starting within a day of the release.

\section{Laboratory chambers}

Results from laboratory growth chambers contrasted somewhat with those from the wetland. In general, nutrients stimulated algae while atrazine inhibited it. Spring water average nutrient concentrations were $184 \mu \mathrm{g} \mathrm{L}^{-1}$ dissolved inorganic nitrogen (DIN), $43 \mu \mathrm{g} \mathrm{L}{ }^{-1} \mathrm{PO}_{4}-\mathrm{P}$, $621 \mu \mathrm{g} \mathrm{L}^{-1} \mathrm{TN}$, and $86 \mu \mathrm{g} \mathrm{L}^{-1} \mathrm{TP}$ (Table 5). Atrazine concentrations stayed near targets, with a mean of 12 and $117 \mu \mathrm{g} \mathrm{L}^{-1}$ for low and high atrazine treatments, respectively (Table 5). Algal biomass (as Chl $a$ ) on tiles had a significant response to both nutrients $(F=7.66, p=0.01)$ and atrazine $(F=4.62, p=0.02)$. Nutrients increased $\mathrm{Chl}$ $a$ by an average of $65 \%(p=0.001)$ over controls, which

Table 4 Cumulative AICc weights $\left(w_{i}\right)$ giving the relative importance of each model parameter for each response variable

\begin{tabular}{lcccrrrrr}
\hline Response variable & \multicolumn{2}{l}{ Relative importance } & & & & \\
\cline { 2 - 8 } & Atrazine & Metolachlor & \multicolumn{1}{l}{ TN } & TP & Atr $\times$ TN & Atr $\times$ TP & TSS & Days \\
\hline Chl $a$ (effect size) & -0.28 & 0.75 & -0.63 & -0.34 & -0.10 & 0.10 & -0.90 & 0.07 \\
AFDM (effect size) & 0.70 & -0.70 & -0.44 & 0.37 & -0.95 & 0.07 & 0.85 & 0.32 \\
Chlorophyll/AFDM & -0.86 & 0.39 & -0.23 & 0.29 & -0.20 & 0.17 & 0.97 & 0.15 \\
Respiration & -0.24 & 0.21 & -0.22 & -0.55 & -0.18 & -0.44 & 0.27 & 0.15 \\
Gross primary productivity & 0.20 & -0.24 & 0.22 & -0.21 & 0.17 & -0.18 & 0.40 & -0.19 \\
Ammonium uptake & -0.19 & 0.22 & -0.22 & 0.20 & -0.14 & 0.11 & -0.16 & -0.75 \\
\hline
\end{tabular}

Variables with a negative relative importance factor had a negative effect on the response variable

$T S S$ total suspended solids; TN total nitrogen; TP total phosphorus; Atr $\times T N$ and Atr $\times T P$ atrazine interaction with TN and TP, respectively 

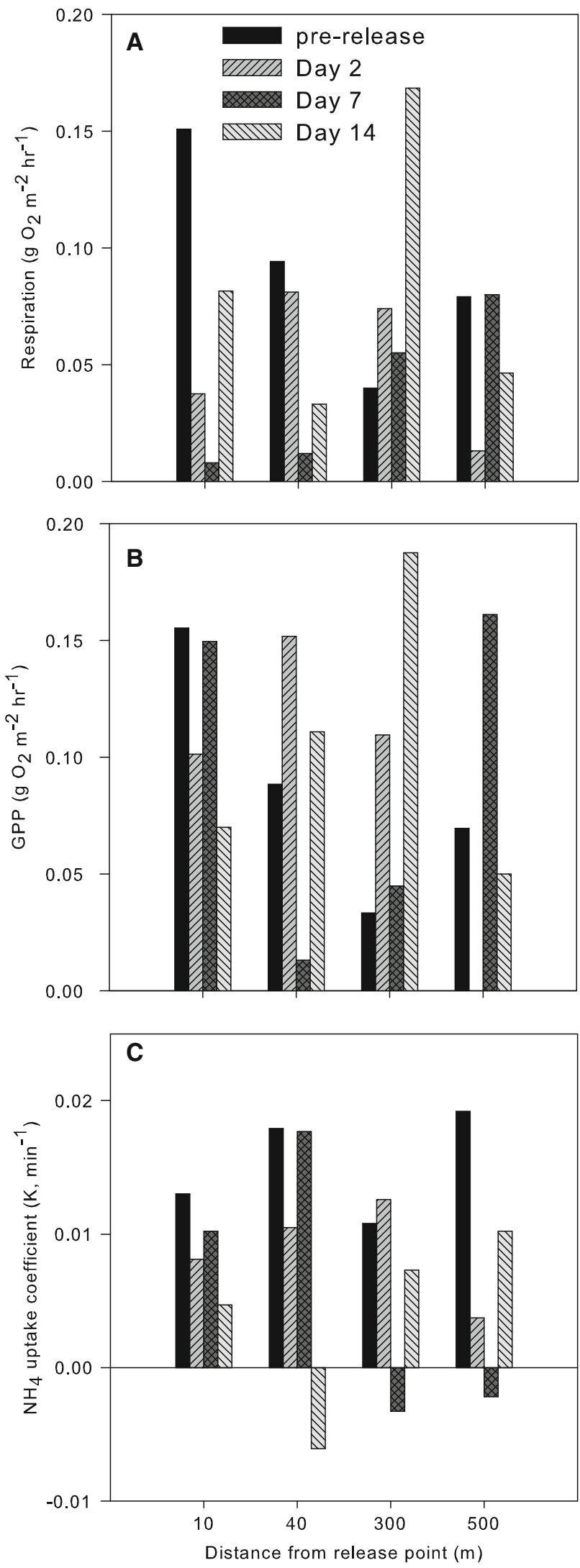

Fig. 3 Wetland tile periphyton metabolism. a Respiration, b GPP, and $\mathbf{c}$ ammonium uptake coefficient averaged $28.9 \mathrm{mg} \mathrm{m}^{-2}$. Low atrazine reduced Chl $a$ by $60 \%(p=0.006)$, and high atrazine reduced Chl $a$ by $30 \%$ ( $p=0.068$, Fig. 5). There was not a significant nutrient and atrazine interaction effect. Mean Chl $a$ in NLA and NHA mixtures (28.9 and $27.1 \mathrm{mg} \mathrm{m}^{-2}$, respectively) were between the NUT, and LA and HA values. Chamber wall Chl $a$ provided a measure of colonization potential among treatments, and trends differed slightly from tiles. Both nutrients $(F=37.3, p<0.001)$ and atrazine $(F=4.83, p=0.017)$ significantly affected accumulation on chamber walls after 20 days. Nutrients increased wall Chl $a$ by $116 \%(p<0.001)$, and the HA treatment reduced wall Chl $a$ by $29 \% \quad(p=0.047)$. The NLA mixture increased wall Chl $a 190 \%$ over the control (Fig. 5).

Periphyton R and GPP was relatively constant over time within each treatment. $\mathrm{R}$ was not impacted by nutrients or atrazine (Fig. 6a). The HA treatment reduced GPP by an average of $37 \%(F=7.78, p=0.013$, Fig. $6 b)$, but there was no observed effect of nutrients or low atrazine on GPP. $\mathrm{NH}_{4}{ }^{+}$uptake rates increased through day $20(F=72.9$, $p>0.001$ ) in all treatments (Fig. 6c). NUT treatments had $68 \%$ lower uptake rates on day 9 , but rates were highly variable, and there was no difference among treatments by day 20 (significant nutrient $\mathrm{x}$ time interaction, $F=3.97$, $p=0.030$ ). On day $3, \mathrm{HA}$ and NHA reduced overall $\mathrm{NH}_{4}{ }^{+}$ uptake rates by 75 and $84 \%$, respectively. Because of significant algal growth on chamber walls during the experiment, day 20 metabolism estimates, which are based on tile dimensions, are likely overestimated.

\section{Discussion}

The strong impact of continuous atrazine and nutrient exposure on periphyton in laboratory chambers was not observed in the wetland. Nutrients and atrazine contributed to periphyton changes, but in the context of typical agricultural runoff mixtures, other pollutants, specifically TSS, were more important. Additionally, periphyton responses were much more complex in the wetland. Wetland periphyton response was greatest near the runoff inflow, but the direction of the response (i.e., stimulation or inhibition) was inconsistent with distance from the input site. This varied longitudinal response suggested a substantial difference in pollutant exposure and/or periphyton susceptibility to pulsed agricultural runoff among adjacent sites. Overall, periphyton structure was more impacted than functional aspects, and runoff had potentially different effects on the autotrophic and heterotrophic components of the periphyton. These structural changes led to significant, but temporary changes in the periphyton structural/functional relationship. 
Fig. 4 Whole system GPP and $\mathrm{R}$ at $10,40,300$, and $500 \mathrm{~m}$ from the runoff inflow point. Note $\mathrm{R}$ rates are shown as grams of oxygen consumed and therefore greater $\mathrm{R}$ rates are more negative. Also note the smaller $y$ axis scale at $300 \mathrm{~m}$
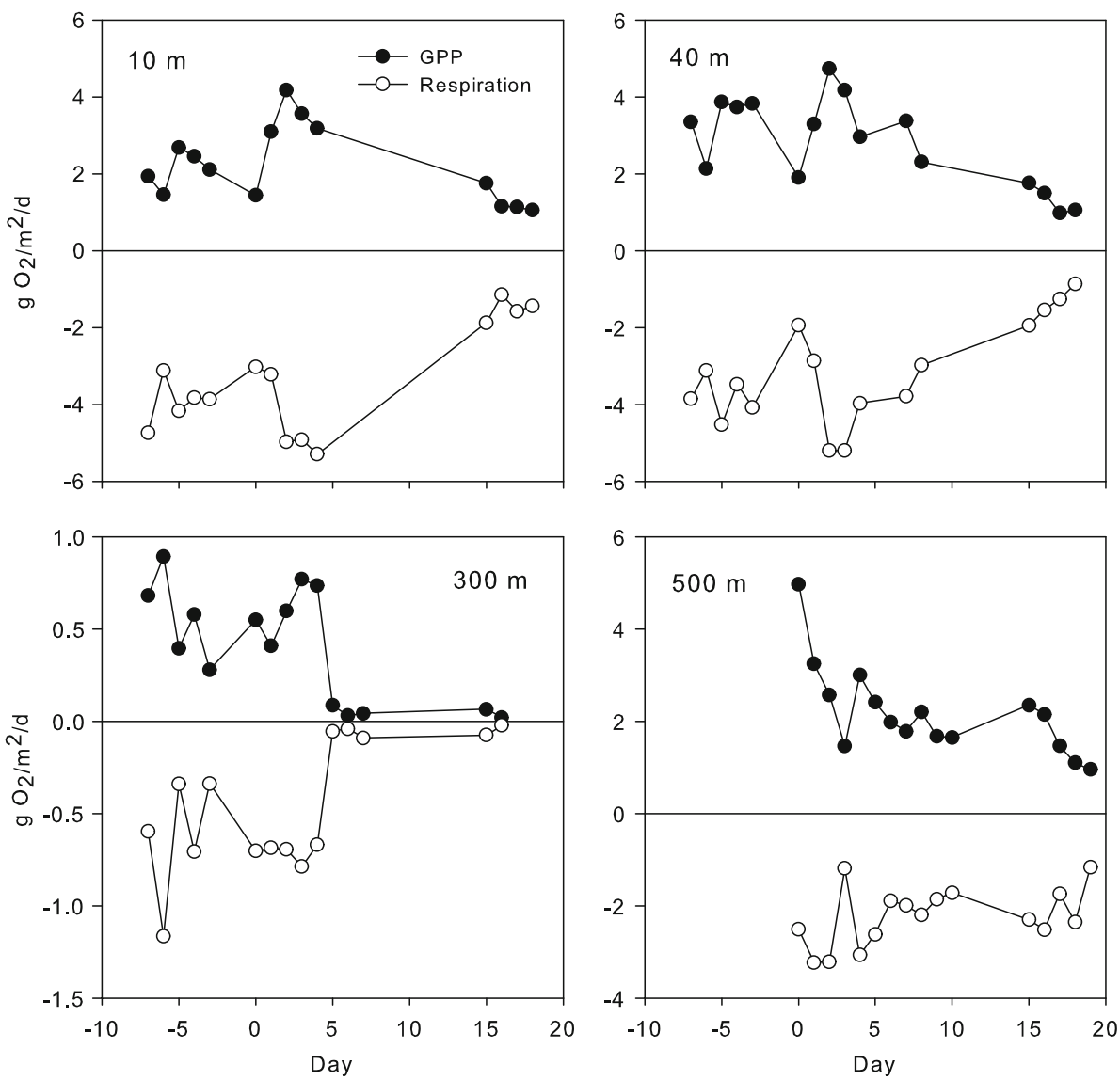

Table 5 Average atrazine and nutrient concentrations $\left(\mu \mathrm{g} \mathrm{L}^{-1}\right)$ in laboratory chambers over the 20-day incubation

\begin{tabular}{llllllrr}
\hline Treatment & Atrazine & $\mathrm{NH}_{4}-\mathrm{N}$ & $\mathrm{NO}_{2}-\mathrm{N}$ & $\mathrm{NO}_{3}-\mathrm{N}$ & $\mathrm{SRP}$ & $\mathrm{TN}$ & $\mathrm{TP}$ \\
\hline Water only & $\mathrm{BD}$ & $\mathrm{BD}$ & $6.8(1.7)$ & $177(50.1)$ & $43.0(70.3)$ & $621(175)$ & $85.5(31.9)$ \\
Control & $\mathrm{BD}$ & $2.7(1.1)$ & $6.2(1.3)$ & $90.4(42.8)$ & $34.2(56.3)$ & $510(111)$ & $79.6(35.9)$ \\
Nutrient & $\mathrm{BD}$ & $3.7(0.9)$ & $8.3(2.0)$ & $696(341)$ & $123(231)$ & $1,263(385)$ & $103(20.8)$ \\
Low atrazine & $11.9(4.2)$ & $1.6(0.5)$ & $6.7(1.6)$ & $105(46.9)$ & $35.4(40.5)$ & $629(134)$ & $94.5(21.3)$ \\
High atrazine & $117(45.4)$ & $1.4(0.6)$ & $6.7(1.6)$ & $128(57.2)$ & $29.8(53.9)$ & $902(858)$ & $88.1(28.6)$ \\
Nutrient + low atrazine & $12.2(4.3)$ & $3.0(1.3)$ & $7.9(2.0)$ & $594(356)$ & $65.2(50.4)$ & $1,108(286)$ & $107(17.0)$ \\
Nutrient + high atrazine & $117(44.6)$ & $2.3(0.7)$ & $11.1(6.2)$ & $932(208)$ & $98.1(49.6)$ & $1,447(304)$ & $137(55.2)$ \\
\hline
\end{tabular}

Standard deviations are in parentheses

$B D$ below detection limit $\left(1 \mu \mathrm{g} \mathrm{L}^{-1}\right)$

Structural response

Algal responses to runoff were spatially inconsistent, as Chl $a$ both decreased (10 and $500 \mathrm{~m}$ ) and increased (40 and $300 \mathrm{~m})$ at adjacent sites during the first week. Sites had considerable differences in both the amount of periphyton change, and physical and chemical exposures during the release. It is unlikely that the mechanisms that caused changes in algal biomass were the same throughout the wetland. For example, the $10 \mathrm{~m}$ site was exposed to more suspended sediment and higher nutrient and herbicide concentrations than the $500 \mathrm{~m}$ site; yet both sites had decreases in periphyton Chl $a$. Also, even though TSS, nutrient, and herbicide concentrations were not greatly different between 10 and $40 \mathrm{~m}$, a shift from inhibition towards stimulation was observed. Prior exposure to herbicides can reduce its impact (Guasch et al. 2007; Tlili et al. 2011). Perhaps periphyton at $40 \mathrm{~m}$ was more tolerant to herbicides in the runoff, as the tributary slough introducing runoff between 10 and $40 \mathrm{~m}$ was likely a frequent source of runoff into the wetland. Also, a positive algal response was also observed at $300 \mathrm{~m}$ where the highest 


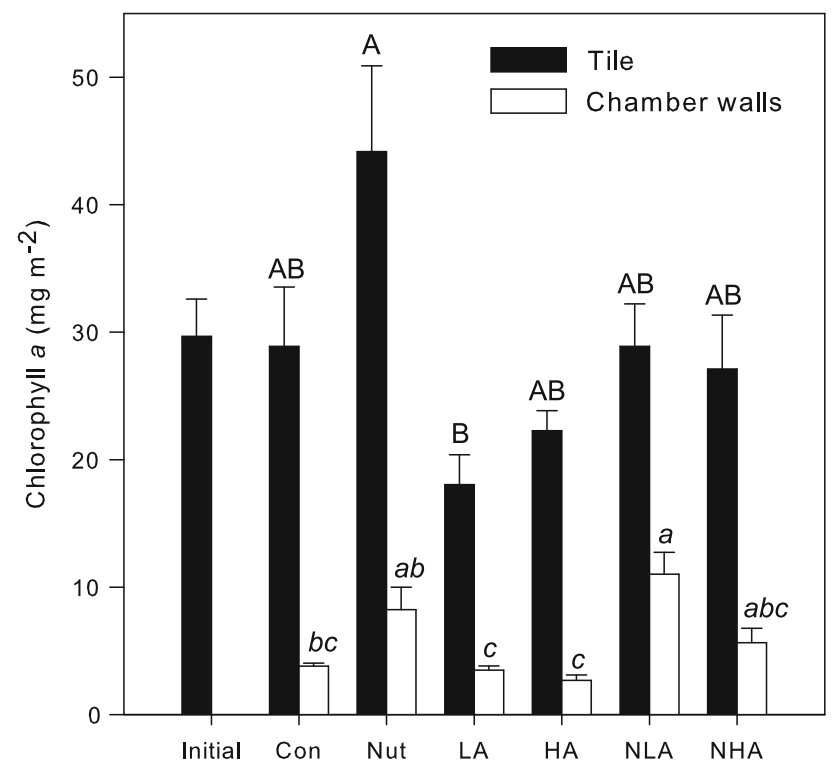

Fig. 5 Laboratory chamber algal biomass on tiles and chamber walls on day 20. Error bars are one standard error. Con control, Nut nutrients only, $L A$ low atrazine $\left(10 \mu \mathrm{g} \mathrm{L}^{-1}\right), H A$ high atrazine $\left(100 \mu \mathrm{g} \mathrm{L}^{-1}\right), N L A$ nutrients + low atrazine, NHA nutrients + high atrazine). Bars with the same letter are not significantly different at $p=0.05$. Tiles are denoted by uppercase letters and chamber walls by italicized lowercase letters

pre-experiment atrazine levels were observed. Despite these distinct variable effects in the wetland, the impact of runoff was spatially restricted as no significant effects were found at $500 \mathrm{~m}$.

Nutrient and atrazine exposure in laboratory chambers had large impacts on algal biomass. However, they had less impact than other pollutants in the context of runoff exposure typical of the Mississippi River Alluvial Plain. Nevertheless, atrazine and nutrients were important drivers, and trends seen in chambers helped explain wetland periphyton response patterns. Atrazine toxicity studies on periphyton often show variable results, including growth stimulation (Shabana 1987; Murdock and Wetzel 2012), inhibition (Guasch et al. 2007), and no effect (Jurgensen and Hoagland 1990). Chambers suggested that atrazine inhibited some periphyton growth in this wetland, but it could stimulate new growth of atrazine tolerant species when atrazine is low and nutrients are high. Following the runoff pulse, long-term exposure of atrazine averaged between 10 and $20 \mu \mathrm{g} \mathrm{L}^{-1}$, similar to the low chamber exposure level. Therefore, atrazine stimulation with high nutrient availability may have contributed to the lower impact of atrazine in this nutrient-rich wetland. Lowered light availability can also decrease the toxicity of atrazine on periphyton (Guasch and Sabater 1998; Guasch et al. 2003), since it acts to lower chlorophyll light harvesting efficiency. Maximum TSS loads following the release were 5-10 times higher than pre-experiment levels, which likely
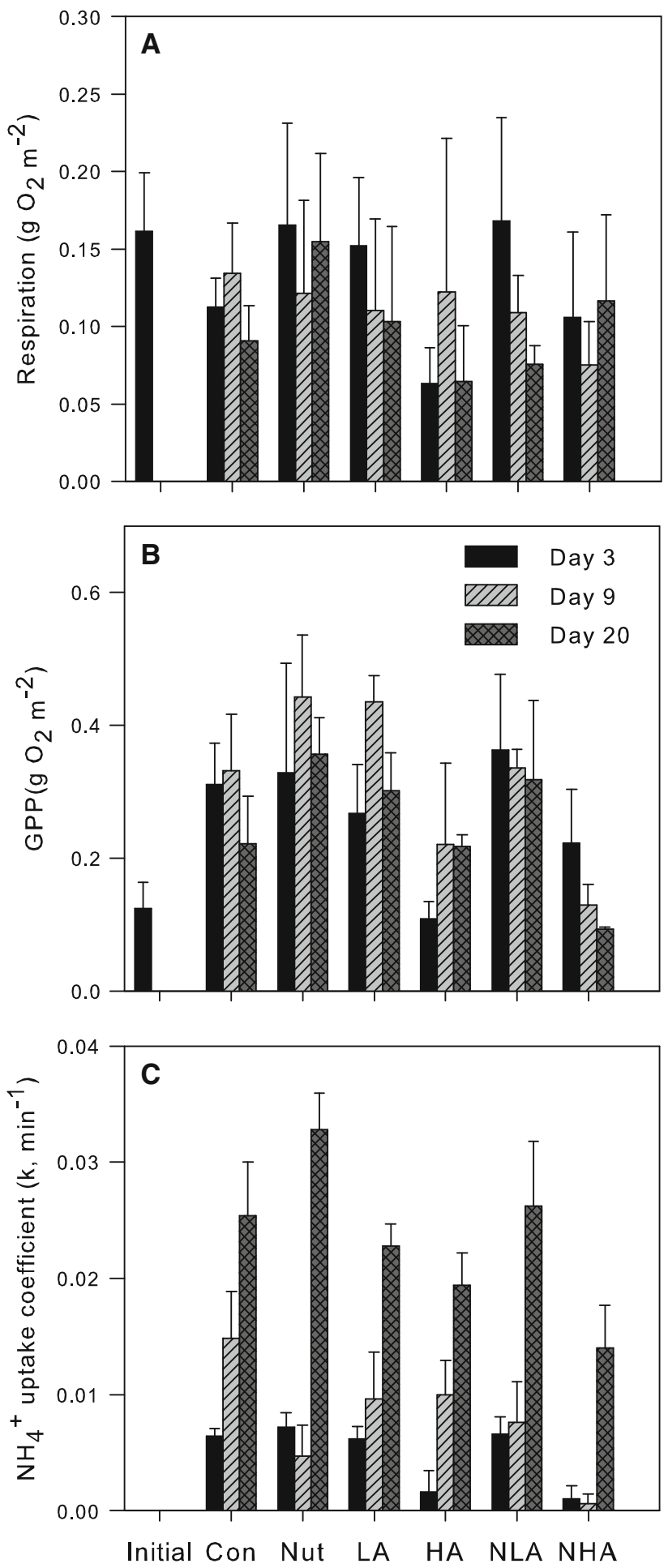

Fig. 6 Laboratory chamber metabolism. a R, b GPP, and c ammonium uptake coefficients (kt). Error bars are one standard error. Con control, Nut nutrients only, LA low atrazine $\left(10 \mu \mathrm{g} \mathrm{L}^{-1}\right), H A$ high atrazine $\left(100 \mu \mathrm{g} \mathrm{L}^{-1}\right)$, NLA nutrients + low atrazine, NHA nutrients + high atrazine

caused substantial shading of periphyton. Little progress has been made at defining concentration breakpoints in atrazine impact on periphyton. Some algal/atrazine trends 
that may help explain our results are (1) in streams, no negative impact on biomass is typically observed below $20 \mu \mathrm{g} \mathrm{L}^{-1}$ (Solomon et al. 1996), (2) biomass stimulation of diatoms and cyanobacteria has mainly been observed with lower atrazine concentrations, $<20 \mu \mathrm{g} \mathrm{L}^{-1}$ (Shabana 1987; Murdock and Wetzel 2012), (3) differential responses among algal species likely contribute to differences in assemblage level responses (Guasch et al. 1998; Lockert et al. 2006), and (4) recovery after atrazine removal can occur within days (Hamala and Kollig 1985), reducing long-term negative impact of atrazine.

Algae's negative correlation with $\mathrm{TN}$ and $\mathrm{TP}$ in the wetland may be a consequence of nutrient saturation by prolonged, high ambient concentrations of $\mathrm{N}$ and $\mathrm{P}$ (Shields et al. 2012). TN above $2 \mathrm{mg} \mathrm{L}^{-1}$ can saturate periphyton growth in streams within this region (Murdock unpublished data) and TN was well above these levels after the release. Additionally, P binding to suspended sediment, and $\mathrm{P}$ saturated periphyton growth, likely contributed to TP's negative regression coefficient. Shading or burying of periphyton by suspended sediment can have a stronger negative impact on periphyton than other pollutants. For example, TSS had a greater impact than atrazine (up to $100 \mu \mathrm{g} \mathrm{L}^{-1}$ ) on periphyton in a Nebraska headwater stream (Jurgensen and Hoagland 1990). Benthic organic matter re-suspended during the release may also explain the large, quick increase in AFDM at $10 \mathrm{~m}$. However, increased AFDM at all stations show that runoff pollutants (including nutrients and atrazine) can increase AFDM. Although chlorophyll increased at some sites, the chl/ AFDM ratio decreased at all sites. Atrazine was a strong driver in reducing this ratio and is consistent with findings that atrazine can be a $\mathrm{C}$ and $\mathrm{N}$ source for bacteria (Giardina et al. 1982). This relative reduction suggests that AFDM increases in the wetland were due more to heterotrophic increases rather than autotrophic reductions. The net impact of runoff is therefore a more heterotrophic periphyton assemblage, potentially accompanied by a net decrease in oxygen production.

\section{Functional response}

Runoff exposure resulted in both temporal and spatial changes in periphyton NPP along the wetland. However, nutrients and atrazine explained only a small portion of GPP and $\mathrm{R}$ variation. This matched periphyton responses in laboratory chambers where there was little impact of either nutrients or atrazine on metabolism, except a reduction of GPP at the highest atrazine concentration (a constant $100 \mu \mathrm{g} \mathrm{L}^{-1}$ ). Periphyton in the field study were exposed to high levels of atrazine ( $\left.>100 \mu \mathrm{g} \mathrm{L}^{-1}\right)$ for only a few hours, and $10-20 \mu \mathrm{g} \mathrm{L}^{-1}$ for approximately 2 weeks. Previous studies on mixed species assemblages have found reductions in algal production at low atrazine concentrations, 0.1-40 $\mu \mathrm{g} \mathrm{L}^{-1}$ (Hoagland et al. 1993; Delorenzo et al. 1999; Pannard et al. 2009; Laviale et al. 2011). Why then was the impact on periphyton metabolism limited?

The pulsed nature of runoff (i.e., addition and subsequent removal of pollutants) likely plays a role in the reduced influence of atrazine on function. At the cellular level, atrazine binding within chlorophyll is reversible (Jensen et al. 1977). Hence, although algae can respond very quickly to the addition of atrazine, it also can recover quickly after atrazine removal. For example, atrazine $\left(216 \mu \mathrm{g} \mathrm{L}^{-1}\right)$ can reduce photosynthetic efficiency in algae in as little as one hour, but recovery can occur within $12 \mathrm{~h}$ of atrazine removal (Laviale et al. 2011). Algae can also recover from long-term exposure relatively quickly. A $100 \mu \mathrm{g} \mathrm{L}^{-1}$ constant atrazine exposure reduced periphyton NPP $23 \%$ within hours in artificial streams and NPP continued to decrease for 14 days, going from net autotrophic to net heterotrophic. However, NPP returned to match control periphyton rates within 16 days of atrazine removal (Hamala and Kollig 1985).

Species-specific responses can also be important in assemblage responses to pollutants because not all species within the assemblage are negatively impacted by atrazine. Cyanobacteria and diatoms are often less susceptible to atrazine toxicity than green algae (Tang et al. 1997; Weiner et al. 2004; Lockert et al. 2006). It is possible that differential responses can lead to a relatively consistent assemblage function as increased productivity of tolerant species make up for reduced production of susceptible species. For example, atrazine can stimulate $\mathrm{N}$ and $\mathrm{P}$ metabolism per unit mass in cyanobacteria, despite a stoppage or reduction in growth rates (Shabana 1987); and in this study, periphyton $\mathrm{NH}_{4}{ }^{+}$uptake rates were largely unaffected by atrazine in both the wetland and in chambers. And although atrazine decreased chlorophyll in laboratory chambers, atrazine stimulated periphyton AFDM and R in the wetland, suggesting possible heterotrophic microorganism growth stimulation. Thus, species composition of the exposed assemblage, in addition to prior herbicide exposure, may be important in overall assemblage metabolic response.

\section{Pollutant interactions}

A key question about nutrient and atrazine mixtures is the relative strength of each on periphyton, and how periphyton responds to simultaneous exposure. Concentrations of each pollutant changes relatively quickly in natural systems, due in part to atrazine degradation and nutrient uptake. These nonlinear changes further complicate predictions. This study supports earlier work showing that atrazine can interact with nutrients both synergistically and antagonistically on periphyton assemblages (Weiner et al. 
2007; Murdock and Wetzel 2012). Under constant exposure, low atrazine concentrations alone reduced $\mathrm{Chl} a$ in chambers, but low atrazine concentrations mixed with nutrients led to greater algal colonization rates. Controlled conditions in chambers showed that when individual pollutants had a significant effect, mixture responses generally fell between that of individual pollutants. Therefore, one pollutant did not completely override the effect of the other, but generally mitigated the effect of the other. In the wetland, individual atrazine and nutrient relationships with periphyton were complex, as nutrients often had negative relationships with periphyton structure and function. The nutrient and atrazine interactions found in the wetland were with AFDM and R, and both the autotrophic and heterotrophic components contribute to these parameters. It is therefore difficult to partition out possible mechanisms of these interactions from wetland results.

The association of metolachlor with increased autotrophic growth is unclear. Atrazine typically has been found to inhibit algal growth more than metolachlor (e.g., Day 1993; Fairchild et al. 1998; Kotrikla et al. 1999), which our data supports. However, there is little evidence of growth stimulation of algae by metolachlor in the literature. The different mechanisms of inhibition (photosynthesis inhibitor vs. cell division inhibitor) may have contributed to algal responses. Unlike atrazine, metolachlor toxicity requires cells being in a particular cycle of division, i.e., the end of the growth cycle (Vallotton et al. 2008). Given periphyton assemblages had colonized for 4 weeks, assemblages were likely in a climax growth phase with relatively low cell division rates.

\section{Ecological implications}

This study provides empirical evidence that the introduction of multiple pollutants in complex mixtures can alter the influence of individual pollutants on aquatic ecosystems. Predicting responses will require knowing not only runoff chemical characteristics, but also the biotic and abiotic conditions of the receiving system. For example, although periphyton metabolism had little response to runoff, or recovered quickly, whole-system GPP and R continued to decrease over time. This suggests that other wetland components contributing to primary production, such as aquatic macrophytes, may take longer to recover from agricultural runoff pollutants than periphyton. Therefore system-level responses to runoff may greatly depend on the relative proportions of periphyton to other aquatic primary producers. Despite the substantial research on periphyton response to atrazine, information concerning in situ longitudinal impacts from runoff-introduced herbicides is lacking. Periphyton near runoff inflows experience very different chemical environments than those further downstream. This study demonstrates that periphyton responses can show a complete reversal within meters downstream. Because of the variable effect of pollutants across concentrations and varying removal/decomposition rates of pollutants within runoff from a single location, predicting responses at the stream reach or watershed scales is difficult. However, knowing locations of inflows, inflow physical and chemical characteristics, and biotic makeup of the receiving water body can be important to understand sub-km effects of runoff on aquatic systems. Future research is needed to measure the impacts of pollutants on individual algal species. A species-specific approach, based on resident periphyton communities, should create better predictions of runoff impact on ecosystem structure and function.

Acknowledgments We thank Alexandra Ashmead, Lisa Brooks, Daniel Warren, and John Massey for field and laboratory assistance. Matt Moore and Traci Hudson provided insightful comments on this manuscript. This work was completed as part of the research program of the Water Quality and Ecology Research Unit of the USDA Agricultural Research Service.

Conflict of interest All authors confirm that there are no conflicts of interests. The experiments comply with the current laws of the country in which they were performed.

\section{References}

APHA (2005) Standard methods for the examination of water and wastewater, 21st edn. American Public Health Association, Washington, DC

Bott TL (1996) Algae in microscopic food webs. In: Stevenson RJ, Bothwell ML, Lowe RL (eds) Algal ecology. Academic Press, San Diego, pp 574-608

Bott TL (2006) Primary productivity and community respiration. In: Hauer FR, Lamberti GA (eds) Methods in stream ecology. Elsevier, Amsterdam, pp 663-690

Burnham KP, Anderson DR (1998) Model selection and inference: a practical information-theoretic approach. Springer, New York

Cohen J (1988) Statistical power analysis for the behavioral sciences, 2nd edn. Lawrence Erlbaum, Hillsdale

Cole JJ (1982) Interactions between bacteria and algae in aquatic ecosystems. Annu Rev Ecol Evol Syst 13:291-314

Day KE (1993) Short-term effects of herbicides on primary productivity of periphyton in lotic environments. Ecotoxicology 2:123-138

DeLorenzo ME, Lauth J, Pennington PL, Scott GI, Ross PE (1999) Atrazine effects on the microbial food web in tidal creek mesocosms. Aquat Toxicol 46:241-251

DeLorenzo ME, Leatherbury M, Weiner JA, Lewitus AJ, Fulton MH (2004) Physiological factors contributing to the species-specific sensitivity of four estuarine microalgal species exposed to the herbicide atrazine. Aquat Ecosyst Health 7:137-146

Dodds WK (2003) The role of periphyton in phosphorus retention in shallow freshwater aquatic systems. J Phycol 39:840-849

Dodds WK, Beaulieu JJ, Eichmilier JJ, Fischer JR, Franssen NR, Gudder DA, Makinster AS, McCarthy MJ, Murdock JN, O'Brien JM, Tank JL, Sheibley RW (2008) Nitrogen cycling and 
metabolism in the thalweg of a prairie river. J Geophys Res Biogsci 113:G04029

Dunlop WP, Cortina JM, Vaslow JB, Burke MJ (1996) Meta-analysis of experiments with matched groups or repeated measures designs. Psychol Methods 1:170-177

Fairchild JF, Ruessler DS, Carlson AR (1998) Comparative sensitivity of five species of macrophytes and six species of algae to atrazine, metribuzin, alachlor, and metolachlor. Environ Toxicol Chem 17:1830-1834

Faust M, Altenburger R, Backhaus T, Blanck H, Boedeker W, Gramatica P, Hamer V, Scholze M, Vighi M, Grimme LH (2003) Joint algal toxicity of 16 dissimilarly acting chemicals is predictable by the concept of independent action. Aquat Toxicol 63:43-63

Gao JP, Maguhn J, Spitzauer P, Kettrup A (1998) Sorption of pesticides in the sediment of the Teufelsweiher Pond (Southern Germany). II: competitive adsorption, desorption of aged residues and effect of dissolved organic carbon. Water Res 32:2089-2094

Giardina MC, Giardi MT, Filacchione G (1982) Atrazine metabolism by Nocardia: elucidation of the initial pathway and synthesis of potential metabolites. Agric Biol Chem 46:1439-1445

Guasch H, Sabater S (1998) Light history influences the sensitivity to atrazine in periphytic algae. J Phycol 34:233-241

Guasch H, Munoz I, Roses N, Sabater S (1997) Changes in atrazine toxicity throughout succession of stream periphyton communities. J Appl Phycol 9:137-146

Guasch H, Ivorra N, Lehmann V, Paulsson M, Real M, Sabater S (1998) Community composition and sensitivity of periphyton to atrazine in flowing waters: the role of environmental factors. J Appl Phycol 10:203-213

Guasch H, Admiraal W, Sabater S (2003) Contrasting effects of organic and inorganic toxicants on freshwater periphyton. Aquat Toxicol 64:165-175

Guasch H, Ivorra N, Lehmann V, Van Beusekom B, Sabater S, Admiraal W (2007) Influence of phosphate on the response of periphyton to atrazine exposure. Arch Environ Contam Toxicol 52:32-37

Hamala JA, Kollig HP (1985) The effects of atrazine on periphyton communities in controlled laboratory ecosystems. Chemosphere 14:1391-1408

Hill WR, Ryon MG, Smith JG, Adams SM, Boston HL, Stewart AJ (2010) The role of periphyton in mediating the effects of pollution in a stream ecosystem. Environ Manag 45:563-576

Hoagland KD, Drenner RW, Smith JD, Cross DR (1993) Freshwater community responses to mixtures of agricultural pesticides: effects of atrazine and bifenthrin. Environ Toxicol Chem 12:627-637

Jassby AD, Platt T (1976) Mathematical formulation of relationship between photosynthesis and light for phytoplankton. Limnol Oceanogr 21:540-547

Jensen KIN, Stephenson GR, Hunt LA (1977) Detoxification of atrazine in three gramineae subfamilies. Weed Sci 25:212-220

Junghans M, Backhaus T, Faust M, Scholze M, Grimme LH (2006) Application and validation of approaches for the predictive hazard assessment of realistic pesticide mixtures. Aquat Toxicol 76:93-110

Jurgensen TA, Hoagland KD (1990) Effects of short-term pulses of atrazine on attached algal communities in a small stream. Arch Environ Contam Toxicol 19:617-623

Knauert S, Escher B, Singer H, Hollender J, Knauer K (2008) Mixture toxicity of three photosystem II inhibitors (atrazine, isoproturon, and diuron) toward photosynthesis of freshwater phytoplankton studied in outdoor mesocosms. Environ Sci Technol 42:64246430
Kolpin DW, Kalkhoff SJ (1993) Atrazine degradation in a small stream in Iowa. Environ Sci Technol 27:134-139

Kotrikla A, Gatidou G, Lekkas TD (1999) Toxic effects of atrazine, deethyl-atrazine, deisopropyl-atrazine, and metolachlor on Chlorella fusca var-fusca. Global Nest Int J 1:39-45

Kröger R, Lizotte RE, Shields FD, Usborne E (2012) Inundation influences on bioavailability of phosphorus in managed wetland sediments in agricultural landscapes. J Environ Qual 41:604-614

Laviale M, Morin S, Creach A (2011) Short term recovery of periphyton photosynthesis after pulse exposition to the photosystem II inhibitors atrazine and isoproturon. Chemosphere 84:731-734

Lima DL, Schneider RJ, Scherer HW, Duarte AC, Santos EB, Esteves VI (2010) Sorption-desorption behavior of atrazine on soils subjected to different organic long-term amendments. J Agric Food Chem 58:3101-3106

Lizotte RE, Shields FD, Murdock JN, Knight SS (2012a) Responses of Hyalella azteca and phytoplankton to a simulated agricultural runoff event in a managed backwater wetland. Chemosphere 87:684-691

Lizotte RE, Shields FD, Testa S (2012b) Effects of a simulated agricultural runoff event on sediment toxicity in a managed backwater wetland. Water Air Soil Pollut. doi:10.1007/s11270012-1287-1

Lockert CK, Hoagland KD, Siegfried BD (2006) Comparative sensitivity of freshwater algae to atrazine. Bull Environ Contam Toxicol 76:73-79

Mandelbaum RT, Wackett LP, Allan DL (1993) Mineralization of the s-triazine ring of atrazine by stable bacterial mixed cultures. Appl Environ Microb 59:1695-1701

Murdock JN, Wetzel DL (2012) Macromolecular response of individual algal cells to nutrient and atrazine mixtures within biofilms. Microb Ecol 63:761-772

Naegeli MW, Uehlinger U (1997) Contribution of the hyporheic zone to ecosystem metabolism in a prealpine gravel-bed river. J N Am Benthol Soc 16:794-804

O'Brien JM, Dodds WK, Wilson KC, Murdock JN, Eichmiller J (2007) The saturation of $\mathrm{N}$ cycling in Central Plains streams: $\mathrm{N}-15$ experiments across a broad gradient of nitrate concentrations. Biogeochemistry 84:31-49

Pannard A, Le Rouzic B, Binet F (2009) Response of phytoplankton community to low-dose atrazine exposure combined with phosphorus fluctuations. Arch Environ Contam Toxicol 57:50-59

Pinckney JL, Ornolfsdottir EB, Lumsden SE (2002) Estuarine phytoplankton group-specific responses to sublethal concentrations of the agricultural herbicide, atrazine. Mar Pollut Bull 44:1109-1116

Pratt JR, Melendez AE, Barreiro R, Bowers NJ (1997) Predicting the ecological effects of herbicides. Ecol Appl 7:1117-1124

Radosevich M, Traina SJ, Hao YL, Tuovinen OL (1995) Degradation and mineralization of atrazine by a soil bacterial isolate. Appl Environ Microb 61:297-302

Rebich RA (2001) Quality of runoff in the Mississippi Delta Management Systems Evaluation Areas project, 1996-1999. In: Rebich RA, Knight SS (eds) The Mississippi Delta Management Systems Evaluation Areas project, 1996-1999. Mississippi State University Information Bulletin 377, pp 154-168

Relyea RA (2009) A cocktail of contaminants: how mixtures of pesticides at low concentrations affect aquatic communities. Oecologia 159:363-376

Riley AJ (2011) Effects of riparian woody vegetation encroachment on prairie stream structure and function with emphasis on wholestream metabolism. $\mathrm{PhD}$ dissertation, Kansas State University, Manhattan 
Rohr JR, Schotthoefer AM, Raffel TR, Carrick HJ, Halstead N, Hoverman JT, Johnson CM, Johnson LB, Lieske C, Piwoni MD, Schoff PK, Beasley VR (2008) Agrochemicals increase trematode infections in a declining amphibian species. Nature 455:1235-1239

Roman AM, Sabater S (1999) Effect of primary producers on the heterotrophic metabolism of a stream biofilm. Freshw Biol 41:729-736

Sartory DP, Grobbelaar JU (1984) Extraction of chlorophyll- $a$ from fresh-water phytoplankton for spectrophotometric analysis. Hydrobiologia 114:177-187

Shabana EF (1987) Use of batch assays to assess the toxicity of atrazine to some selected cyanobacteria. I. Influence of atrazine on the growth, pigmentation and carbohydrate contents of Aulosira fertilissima, Anabaena oryzae, Nostoc muscorum and Tolypothrix tenuis. J Basic Microb 27:113-119

Shields FD, Pearce CW (2010) Control of agricultural nonpoint source pollution by natural wetland management. J Environ Eng 4:62-70

Shields FD, Lizotte RE, Knight SS (2012) Spatial and temporal water quality variability in aquatic habitats of a cultivated floodplain. River Res Appl. doi:10.1002/rra.1596

Smith S, Cooper CM, Lizotte RE (2007) Pesticides in shallow ground water in the forested natural wetland riparian area of the Beasley Lake Watershed, Mississippi, USA, 2001-2005. Int J Ecol Environ Sci 33:223-231

Solomon KR, Baker DB, Richards RP, Dixon DR, Klaine SJ, LaPoint TW, Kendall RJ, Weisskopf CP, Giddings JM, Giesy JP, Hall LW, Williams WM (1996) Ecological risk assessment of atrazine in North American surface waters. Environ Toxicol Chem 15:31-74
Steinman AD, Lamberti GA, Leavitt PR (2006) Biomass and pigments of benthic algae. In: Hauer FR, Lamberti GA (eds) Methods in stream ecology. Elsevier, Amsterdam, pp 357-379

Tang JX, Hoagland KD, Siegfried BD (1997) Differential toxicity of atrazine to selected freshwater algae. Bull Environ Contam Toxicol 59:631-637

Tang J, Hoagland KD, Siegfried BD (1998) Uptake and bioconcentration of atrazine by selected freshwater algae. Environ Toxicol Chem 17:1085-1090

Tlili A, Montuelle B, Berard A, Bouchez A (2011) Impact of chronic and acute pesticide exposures on periphyton communities. Sci Tot Environ 409:2102-2113

Vallotton N, Moser D, Eggen R, Junghans M, Chèvre N (2008) $S$-metolachlor pulse exposure on the alga Scenedesmus vacuolatus: effects during exposure and the subsequent recovery. Chemosphere 73:395-400

Voets JP, Meerschman P, Verstraete W (1974) Soil microbiological and biochemical effects of long-term atrazine applications. Soil Biol Biochem 6:149-152

Wackett L, Sadowsky M, Martinez B, Shapir N (2002) Biodegradation of atrazine and related s-triazine compounds: from enzymes to field studies. Appl Microb Biotechnol 58:39-45

Weiner JA, DeLorenzo ME, Fulton MH (2004) Relationship between uptake capacity and differential toxicity of the herbicide atrazine in selected microalgal species. Aquat Toxicol 68:121-128

Weiner JA, DeLorenzo ME, Fulton MH (2007) Atrazine induced species-specific alterations in the subcellular content of microalgal cells. Pestic Biochem Phys 87:47-53

Zheng SQ, Cooper JF (1996) Adsorption, desorption and degradation of three pesticides in different soils. Arch Environ Contam Toxicol 30:15-20 